\title{
Science Communication Language in Chinese New Media: Evolution, Characteristics and Trend
}

\section{Li Zhao}

\begin{abstract}
Evolution of science communication in China has been marked by several significant transitions: governmental promotion has being replaced by more spontaneous, non-governmental involvement; new media is preferred to traditional media; the agents of science popularization have expanded from professional scientists to "grass-roots" netizens. The expansion of agents, together with changes in the modes of science communication and reception habits rom new media, has brought forth changes of language style and features in science communication. This article aims to study the language of science websites and scientific micro-blogging (Chinese version of Twitter). Via an in-depth analysis on new media language with emphasis on its features and cultural symbols, this paper gauges the trends of new media language development in science communication, which provides a reference for the science commutation practice.
\end{abstract}

Index Terms - New media, science communication in China, language features, trends.

\section{INTRODUCTION}

With the development of information technology, the network and various forms of mobile terminals have become important channels for general public to access scientific information and knowledge. Digital, real-time, interactive and other features of new media, not only revolutionarily lower threshold of science popularization products, but also bring a totally new experience of science communication in terms of time, space, and information forms.

New media, while proved as an efficient platform for science communication, also raises questions for the research and development of science communication products. This is particularly true when a series of new situations are considered: the expanding of agents in science communication, the continuously updated modes of science popularization and public reception.

One of the changes is exemplified in a sensational event in China. After Japan's Fukushima nuclear accident in 2011, a message "iodized salt could prevent radiation" was quickly spread through micro-blogs, SNS and other kinds of social media. Citizens of major Chinese cities, driven by rumors alleging that salt supplies were contaminated, rushed into groceries for stored salt products. This incident, later known as "Salt Maniac", indicates that Chinese authority and experts have partly lost discourse power to some extent in new media. It appears that the Chinese people no longer blindly believed in authorities and experts. Instead, they voluntarily participate in the network interactions, in a form of individual expression in science communication activities. Mapped into

Manuscript received May 8, 2013; revised July 9, 2013.

Li Zhao is with the University of Science and Technology of China, Southwest University of Science and Technology, China (e-mail: zhaoli8533@163.com). this intellectual background, it is important to understand how the authority and reliability of scientific information and dissemination could be ensured, and how scientific language mechanisms and expression patterns are innovated.

\section{Language Evolution in New Media Promoted by EXPANSION OF AGENTS IN SCIENCE COMMUNICATION}

Since the founding of PRC in 1949, the subject of science popularization has been significantly changed and developed. In the earlier days of PRC, governmental organizations like Bureau of Science Popularization under the Ministry of Culture, National Association of Science and Technology Popularization, China Scientific Institution were supposed to be responsible for science popularization. [1] Since the "Reforming and Opening up" in 1978, other semi-governmental organizations like Association of Chinese Science Writers, and Research Institute of Science Popularization of China have been set up successively. In the 21 st century, the emergence of new media fuels a rapid development of civil power in science popularization, which is evidenced in the fact that young science practitioners enjoy a very strong presence in on-line science popularization.

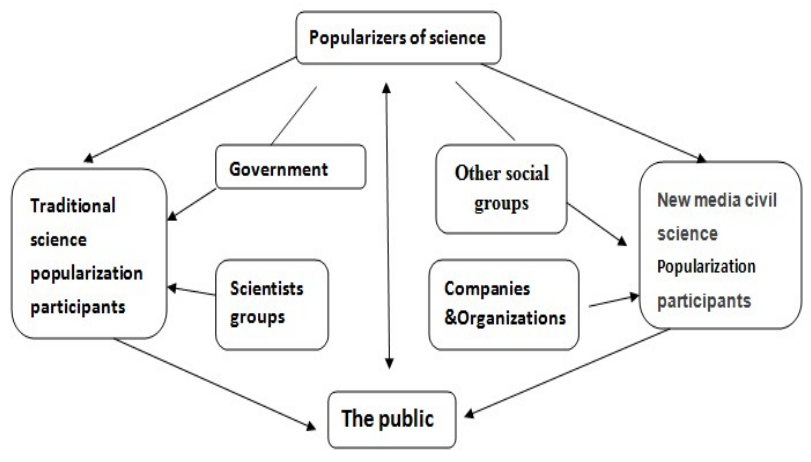

Fig. 1. Fusion and evolution of the subject and object of science communication in new media context.

In the Internet era of science communication, traditional agents of science popularization (governmental organizations and scientists groups), together with other less "traditional" agents, start to appreciate the meaning and value of science communication. Fig. 1 represents the gradually formed relationship changes between science popularization agents and the public in the new media context, depicting the "we media science communication", the mutual conversion processes and patterns between the subject and object of science communication. It also indicates the inherent driving force and the public's inner requirements of science communication, and the changes of ideas and social functions of science communication. In the practice of modern science communication, traditional science subject and object have 
changed into a process of multidirectional interaction with participation from scientific community, governmental organizations, media, other social organizations and the public, from a process of condescending one-sided communication, become into a stereo social communication system from the cause of traditional science popularization which just involved the minority.

The new media forms in the environment of media convergence, deepen and promote the evolution and development of " we media self-science-popularization" model. To build a competitive science product continuously, online science popularization industry needs further exploration and innovation on science communication language, which necessitates science workers with decent understanding of the philosophical connotation of internet. Internet content creation of science-popularizing products, first and foremost means to break the traditional science popularizations' "preaching" and "authoritative" language model.

To satisfy the internal needs of the audience, the adoption of new philosophical thinking on science communication language is needed, which in return results in new perspectives and changes in style. These changes have been marked by an irreversible trend where a more traditional podium style of knowledge dissemination has been challenged by more spontaneous sharing of knowledge. Dissemination and popularization of science in internet field familiar by the younger generation, needs a self-deprecating attitude downing from authority platforms, and accessing the public in a suitable and well-known new media language. This may pose new challenges and questions for developers of science popularization products, as they are expected to produce authoritative, valid contents without adopting a preaching or indoctrinating style.

\section{LANGUAGE ANALYSIS ON MAJOR SCIENCE POPUlariZATION PRODUCTS IN NEW MEDIA}

\section{A. Science Popularization Websites: the Evolution of Science Communication Language}

Currently, most of the online science popularization products in China are from websites. According to the horizontal comparison, the Chinese scientific websites may be roughly divided into four categories: portal web, Wikipedia web, subject web and theme web [2]. While compared vertically, these websites can be categorized by their affiliations, as "State" or "Private" ones. This categorization is exemplified with prototypical websites in Table I. It is interesting to note that these two categories of websites are different in terms of linguistic style: while State websites are represented with more formal, distant names, private websites are named with more friendly, informal words.

As official internet dissemination channels, "National" science popularization websites are characterized by great reputation, heavy duty and high authority. However, many of the "state" popular science websites experience particular difficulty in attracting prospectus readership, presumably for its impersonal content, problematic propagation angle and obscure scientific language. It is found through the analysis that State websites are marked with obscure, incomprehensible jargons and an ineptitude in understanding that the essence of science popularization is to present obscure scientific knowledge in daily language. It is also interesting to note that State websites are overloaded with news stories concerning daily meetings and other administrative activities. In so doing, linguistic style of the State websites is much closer to that of typical journalism, and thus further away from that of science language. Besides factors in relation to linguistic style, the unpopularity of State science popularization websites can also be explained by other factors ranging from slow website upgrade, a limited vision on the development of science and technology, to understaffed projects and commercialized web design.

\begin{tabular}{|c|c|}
\hline $\begin{array}{c}\text { "State" Science } \\
\text { Popularization Websites }\end{array}$ & $\begin{array}{c}\text { "Private" Science } \\
\text { Popularization Websites }\end{array}$ \\
\hline China popular science Website & Silk Road Astronomy \\
\hline China Popular Science Expo & Mysterious Earth \\
\hline $\begin{array}{c}\text { China Popular Science } \\
\text { Resource Sharing Network }\end{array}$ & Shell Network \\
\hline $\begin{array}{c}\text { China Popular Science Alliance } \\
\text { Network }\end{array}$ & Sony Dream Exploration \\
\hline China Popular Science City & Endless Sky \\
\hline $\begin{array}{c}\text { China Children's Popular } \\
\text { Science Channel }\end{array}$ & Space Art \\
\hline $\begin{array}{c}\text { China Public Popular Science } \\
\text { Network }\end{array}$ & Biological Valley \\
\hline
\end{tabular}

In an introductory treatise on science popularization, Q.L. Yuan rightly observed that the aim of science popularization is to explain the advancement of science and technology in accessible language for the general public so as to help them understand science. [3].This aim is certainly compromised by problematic linguistic style of State science popularization websites. At present, China is lack of popular science resource supply, large differences in quality and level of popular resources; attraction is weakling, these all unable to meet public needs. Sate popular science websites are supposed to lead with example and they have to take the initiative to attract the public's feedback on the language from a favorable change in science, to address and improve their web presence of other problems.

State popular science website can learn from private science websites in terms of science product model and language style. While retaining the authority of science, State popular science website should take the initiative to try friend sharing formula language of science. State popular science website should be simple blocks of color, capable of layout, a wealth of information, vivid expression, initiative to attract the public awareness and understanding of science to click in order to improve the traditional one-way dissemination of science and technology popularization effects of rigid.

\section{B. Science Popularization of Micro-Blog. "Micro-Stylistic" from Birth to Active}

Nowadays, "Micro-content" has become a new network popular for a long timer. They are small, low cost or no cost of online media contents produced by individual users, including the "micro" form of internet product (e.g., micro movie, micro novel, and weibo). The style of "micro" creates 
the content of "micro", while the content forming the vitality of the "micro" language. Since the rise of weibo in China, the emerging network mode of transmission gradually become the centre of online communication, and thus provides a new possibility for science popularization: doing science popularization through weibo (or micro-blog). The rise of popular micro-blog provides a new mode of network science, Opened a new era of grassroots science prelude.

Popular micro-blog is a model of product of public network era of popular science. It stereoscopically realized a transition from the "public understanding of science" to "public participation in science", and constructs a "scientific micro era" that witnesses a transition from the authority of science to scientific grass-roots civil participation. A survey indicates that micro-bloggers engaging in science popularization include professional researchers, teachers in colleges and universities, science writer, journalist, editor of science of science, and science fans [4]. In general, these micro-bloggers, majority of which are well-placed in the establishment, enjoys disciplined academic training, rigorous logic academic authority, and social discourse right. Among these micro-bloggers, professional researchers, university teachers are equipped with scientific expertise for understanding science, and thus enjoy a degree of social credibility in science popularization. And science writer, science journalist, science editor, with long-term career for popular science, specialize in the scientific analysis, which gives them an edge in understanding the principles, thinking, and method of science literature. These groups represent the grassroots era of science communication science subjects expansion. Their group identity showed a professional backgrounds required by "micro" popular science content writers in spreading scientific knowledge.

\begin{tabular}{|c|c|c|c|}
\hline $\begin{array}{l}\text { Name of scientific } \\
\text { Micro-blogs }\end{array}$ & $\begin{array}{l}\text { Micro- } \\
\text { blogs }\end{array}$ & $\begin{array}{l}\text { Fans/ } \\
\text { Audience }\end{array}$ & Real-name Authentication \\
\hline $\begin{array}{l}\text { Tencent-Nuts Shell } \\
\text { Network }\end{array}$ & 8791 & 891309 & $\begin{array}{c}\text { Nuts Shell Network Official } \\
\text { micro-blog }\end{array}$ \\
\hline Sina - Nuts Shell Network & 16280 & 872012 & $\begin{array}{l}\text { Nuts Shell Network Official } \\
\text { micro-blog }\end{array}$ \\
\hline Sina - Ji Thirteen & 9335 & 680282 & $\begin{array}{c}\text { Nuts Shell Network CEO } \\
\text { Founder of Scientific Squirrel Org. }\end{array}$ \\
\hline $\begin{array}{l}\text { Sina-Scientific Commentary } \\
\text { Jia Hepeng }\end{array}$ & 1385 & 3521 & $\begin{array}{l}\text { Founder of Science Media Centre } \\
\text { "Science News" former editor }\end{array}$ \\
\hline Sina-Science micro Fairy & 2247 & 497 & Popular Science Press \\
\hline $\begin{array}{l}\text { Sina-Pudong Popular } \\
\text { Science }\end{array}$ & 2383 & 3263 & Shanghai Pudong Science Association \\
\hline $\begin{array}{l}\text { Sina-Xinmin Popular } \\
\text { Science Cafe }\end{array}$ & 534 & 680 & $\begin{array}{l}\text { public science lectures co-sponsored by } \\
\text { New People's Daily and the Shanghai } \\
\text { Science Association }\end{array}$ \\
\hline $\begin{array}{l}\text { Sina-Xinmin Popular } \\
\text { Science,Lv Xiuqi }\end{array}$ & 1442 & 1797 & $\begin{array}{l}\text { Popular Science Press } \\
\text { Books Division Editor }\end{array}$ \\
\hline $\begin{array}{l}\text { Sina-Popular Science to be } \\
\text { in the end }\end{array}$ & 460 & 203 & A Grass Root Author in Beijing \\
\hline
\end{tabular}

"Nuts Shell Network", a well-received science popularization website among the general public, government, and scientific and cultural communities in China, introduces a set of successful micro-blogging mechanism since it launched micro-blogging service. [5] They developed a specialist team of micro-blog creation in order to ensure the quality of micro- blogging content and effectiveness. For years, the popular science micro-blogs of the "Nuts Shell Network" enriches the content of network science, fills the drawbacks of other network science application modes, stimulates the public's enthusiasm and interest in science, and eventually becomes a non-governmental science micro-blog with the most fans and the highest popularity.

Table II statistics the names and dynamism of some repetitive scientific micro-blogs in China. As it shown, Nuts Shell Network Micro-blog has attracted the most public attention and participation. It is also visible from the table, in terms of the communication effects of personal scientific workers, only a very few individuals with celebrity benefits have discourse and influence in the new media field of science communication.

In the era of "we media" and "media convergence", the rise and growth of non-governmental popular science groups has broken the traditional mode of science communication and language style, and established an easier communication, easier participation bridge between public and scientists, or put in other words, between information and scientific knowledge. This makes popular science micro-blogging has a unique and important diffusion propagation function. This positive function is rooted in its language style and expression. Micro-language of popular science will help to strengthen interaction between research peers, and help attracting public active participation online and offline.

Popular Science "micro" language expand the audience by breaking the monopoly of traditional science media discourse, breaking the traditional way of reading and inherent science and language expression patterns to short, lean, lively, illustrated language style. A minimalist form of micro-blogging known as "one word blog" can be circulated through mobile phone, PC, tablet computers and other forms regardless of time and space. In this case, terminals and media are converted into one. The communication mode of scientific micro-blogs in Fig. 2, with the characteristics of micro-style, fast transmission and open path, which displays a full route of science communication in an interactive and cycling pattern from the scientific topic gathering to self-transmission.

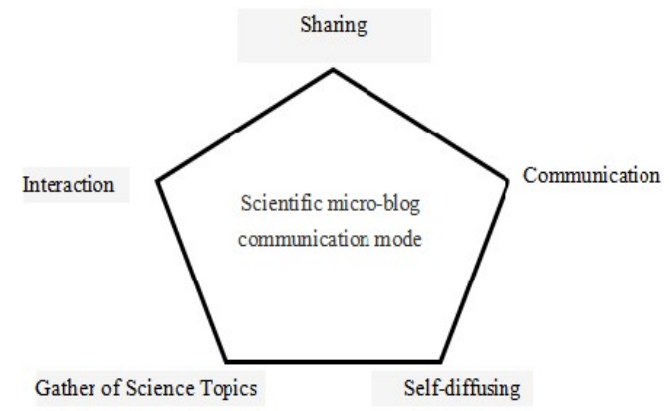

Fig. 2. Communication mode of scientific micro-blogs.

However, language of scientific micro-blogging also harbors negative effects For example, since the language is over-compacted, scientific micro-blog's content and the dissemination of information is often not comprehensive enough. In addition, many non-governmental science micro-blogging suffers problems of inaccurate language, low authority and credibility, all of which attributable to low threshold and the lack of checks in micro-blogging. Scientific micro-blogging may also trigger leakage of classified science and technology information, the infringement of copyrighted materials, and displacement of original texts in 
re-contextualization.

\section{Characteristics AND DEVElOPMENT TREND OF NEW Media SCIENCE COMMUNiCATION LANGUAGE}

In the new media era, the public's reception mode of science communication is characterized by a deconstruction of traditional communication modes, which means that it is quite different from the structured and linear models known for long. In order to avoid the loss of discourse edge in communication, the dissemination of basic scientific research results must be channeled to the general public through science communication language that are adapted to the new media platform expressions. [6]

Based on the language status analysis of internet science popularization products, this section aims to sort out and outlook the characteristics and laws governing development of scientific language, which adapts to the new media science communication. Language of science popularization products in new media, preliminary presents its characteristics and trends: a diverse expression of linguistic notation, an integration of multi-characteristics language entities and multi- categories of languages.

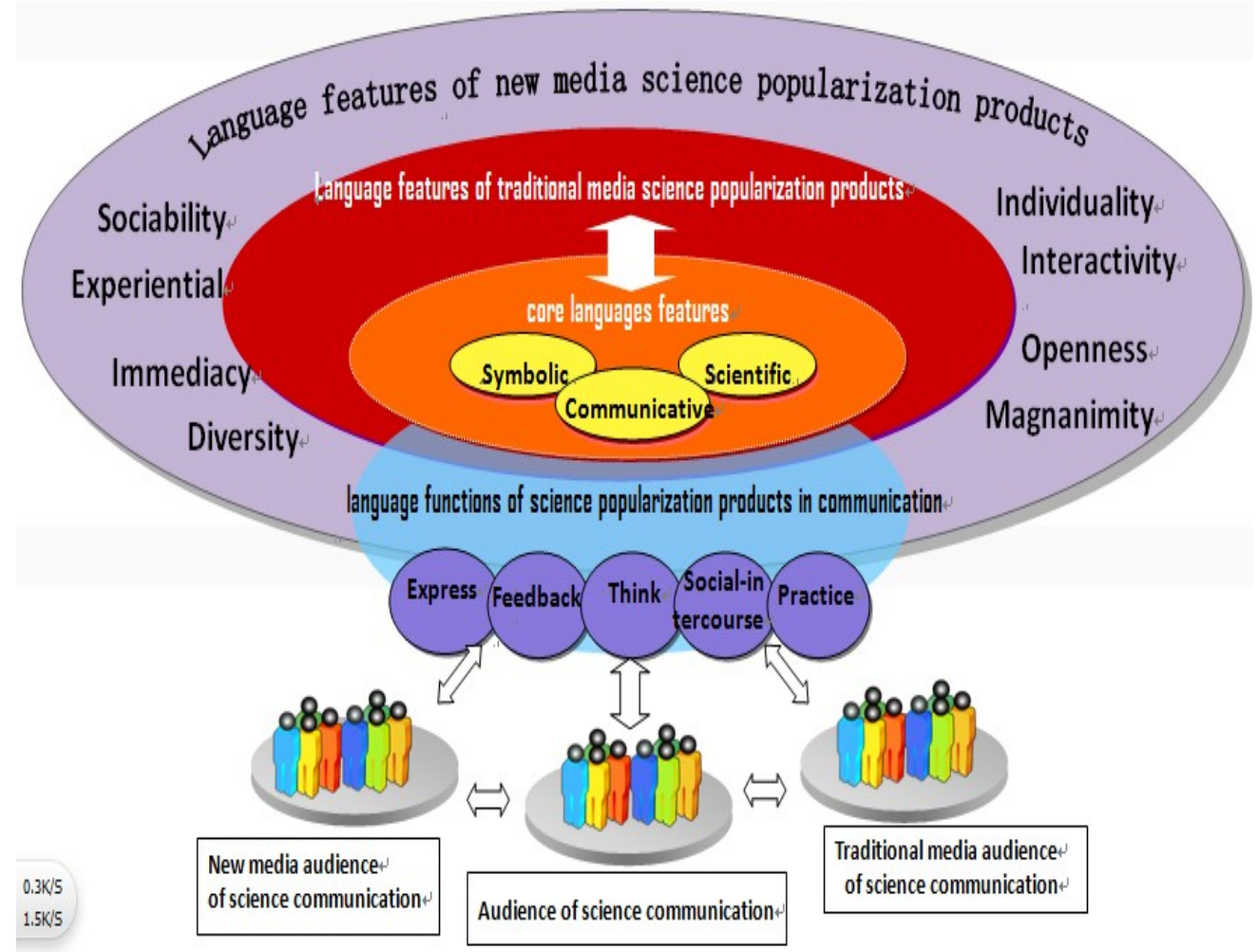

Fig. 3. Diagram of language features relations between new media and traditional science popularization products.

A. Science Popularization Language of New Media Inherited Advantages from Traditional Science Popularization Language

Science communication is a process in which the concept "communication" and that of "science" converges.[7] It understands and treats science with the communication concepts of "multivariate, equality, open and interaction". Science communication is a new stage followed by traditional science popularization and Public Understanding of Science (PUS), but it pays more attention to the new idea of "second order transmission" and the bidirectional interactions between the communicators and receivers.

The essence of science popularization creations in any media context is a process to popularize specialized knowledge into daily life. Scientifically is the life of science popularization products. [8] The traditional science popularization language insists on the fusion of scientifically and popularity, some of which even have a combination of literariness and thoughtfulness. The language advantages and relations between traditional and new media science popularization products are summarized in Fig. 3.

Fig. 3 depicts that science popularization language of new media inherits and carries forward the language advantages from traditional science popularization products, which appears new characteristics and new functions in science communication. The advantages of new media could improve the expression disadvantages of traditional science popularization products. [9]Languages of science popularization in new media are full of humanism and thoughtfulness, which combines the key, difficult and interesting points of scientific knowledge three-in- one.

\section{B. The Fusion of Multiple-Characteristics and Trends of} Science Communication Language in New Media Context

Science popularization language in new media emphasizes a fusion of interactive and experimental process in communication. In the language design and application of network products of science popularization, the most widely used language is text, followed by pictures, sounds, images and animations, etc. Network products of science popularization, such as virtual digital library, experimental museum of science and technology, scientific fictions and movies, need more interactive, experiential and perceptual language design to bring audience impressive feelings during the extensive science reading in new media. 
TABLE III: Science Popularization Language in New Media: FeAtures, APPlicAtion \&EFFects

\begin{tabular}{|c|c|c|c|}
\hline $\begin{array}{c}\text { Science } \\
\text { popularization } \\
\text { language features in } \\
\text { new media }\end{array}$ & $\begin{array}{l}\text { Representative applications } \\
\text { of science popularization } \\
\text { products in new media }\end{array}$ & $\begin{array}{l}\text { Corresponding effects in science } \\
\text { communication }\end{array}$ & Impacts on audience \\
\hline $\begin{array}{l}\text { fusion of massive } \\
\text { amounts and } \\
\text { personalized } \\
\text { expression } \\
\end{array}$ & $\begin{array}{l}\text { popular science web pages; } \\
\text { popular science micro-blogs \& } \\
\text { Other scientific social media }\end{array}$ & $\begin{array}{l}\text { further enriches the contents and } \\
\text { forms in scientific communication, } \\
\text { good to promote personalized popular } \\
\text { science practice }\end{array}$ & $\begin{array}{l}\text { strongly inspires self-consciousness } \\
\text { \&citizen participation in science } \\
\text { popularization practice }\end{array}$ \\
\hline $\begin{array}{l}\text { text narrative \& } \\
\text { audiovisual } \\
\text { entertainment }\end{array}$ & $\begin{array}{c}\text { design of science\& } \\
\text { technology venues; popular } \\
\text { science network games, RAP, } \\
\text { MTV, etc } \\
\end{array}$ & $\begin{array}{l}\text { entertaining science communication } \\
\text { with musical, artistic }\end{array}$ & $\begin{array}{l}\text { enhances the taste and interest of both } \\
\text { communicators \& audience }\end{array}$ \\
\hline $\begin{array}{c}\text { interactive } \\
\text { \&experiential }\end{array}$ & $\begin{array}{c}\text { popular science BBS,post bars, } \\
\text { micro-blogs \& SNS } \\
\end{array}$ & $\begin{array}{c}\text { two-way interactive communication } \\
\text { experience }\end{array}$ & $\begin{array}{c}\text { improve effectiveness \& depth of public } \\
\text { understanding science (PUS) }\end{array}$ \\
\hline $\begin{array}{l}\text { "micro-style" \& } \\
\text { simplicity }\end{array}$ & $\begin{array}{c}\text { popular science text } \\
\text { messages, micro-blogs,micro- } \\
\text { movies } \\
\text { \&micro-animations }\end{array}$ & $\begin{array}{l}\text { 1)brings speed improving, easy } \\
\text { operation\& a dynamic } \\
\text { communication proc\& less unified of } \\
\text { scientific knowledge } 2 \text { ) lack of } \\
\text { control causing the lack of credibility } \\
\text { to some extent }\end{array}$ & $\begin{array}{l}\text { 1) science information \& rumors spread } \\
\text { together, audience are difficult to hear true } \\
\text { or false 2) create an easy media platform } \\
\text { for public participation in science } \\
\text { communication, cause the rise of citizen } \\
\text { science popularizers }\end{array}$ \\
\hline $\begin{array}{l}\text { digital technology } \\
\text { language \& expansion } \\
\text { of intertextuality }\end{array}$ & $\begin{array}{l}\text { popular science micro-blogs, } \\
\text { micro-movies \& } \\
\text { micro-animations }\end{array}$ & $\begin{array}{l}\text { updates the digital applications in } \\
\text { science transmission technology; } \\
\text { diversifies the expressions of science } \\
\text { communication }\end{array}$ & $\begin{array}{l}\text { develops a new way of popular science } \\
\text { reading, changes the traditional linear } \\
\text { scientific text reading habits }\end{array}$ \\
\hline $\begin{array}{l}\text { virtual reality \& art } \\
\text { reality of language }\end{array}$ & $\begin{array}{l}\text { popular science games, micro } \\
\text { movies and virtual reality } \\
\text { modeling language (VRML) }\end{array}$ & $\begin{array}{c}\text { gains real or imagined } \\
\text { science communication experience }\end{array}$ & brings audience "super realism" feeling \\
\hline $\begin{array}{l}\text { language } \\
\text { internationalization } \\
\text { \&network } \\
\text { connectivity } \\
\end{array}$ & $\begin{array}{c}\text { popular science web } \\
\text { pages,SNS and other social } \\
\text { media }\end{array}$ & $\begin{array}{l}\text { pushes forward liberalization of } \\
\text { science communication in level \& } \\
\text { connotation }\end{array}$ & $\begin{array}{c}\text { conducive to cultivate audience a dynamic, } \\
\text { mesh and open way of thinking }\end{array}$ \\
\hline $\begin{array}{c}\text { real-time } \\
\text { \&"not-going-deep" }\end{array}$ & popular science micro-blogs & $\begin{array}{c}\text { starts "instant- } \\
\text { science-popularization" era, } \\
\text { accelerates science communication } \\
\text { cycle }\end{array}$ & $\begin{array}{l}\text { convenient for interpersonal } \\
\text { communication but not conducive to deep } \\
\text { thinking }\end{array}$ \\
\hline $\begin{array}{l}\text { symbol diversity } \\
\text { \& multi-level } \\
\text { language entity }\end{array}$ & $\begin{array}{l}\text { popular science texts, } \\
\text { micro-blogs, animations }\end{array}$ & $\begin{array}{l}\text { dismantles traditional unified } \\
\text { scientific language structure }\end{array}$ & $\begin{array}{l}\text { brings innovation \&rethinking on science } \\
\text { communication language \& style }\end{array}$ \\
\hline $\begin{array}{l}\text { links and hypertext } \\
\text { language }\end{array}$ & $\begin{array}{l}\text { popular science web pages } \\
\text { \&micro-blogs }\end{array}$ & $\begin{array}{l}\text { easy to create homogeneity of science } \\
\text { popularization products \& contents }\end{array}$ & $\begin{array}{l}\text { subverse traditional narrative mode, } \\
\text { reading habits \& reading psychology }\end{array}$ \\
\hline
\end{tabular}

The language design of science popularization in new media also emphasizes a fusion of story-telling and entertaining in science communication: edutainment. [10]What kind of internet language of science popularization is more acceptable by the public? A video clips was widely forwarded and transmitted on internet by the young science and technology enthusiasts in the world in 2012 , it is a scientific music video full of imagination and innovation : the physicists from European Organization for Nuclear Research (CERN) express science in dynamic gestures and rhythmic RAP language. . ${ }^{1}$ At the same time, students started collecting scientific performances in RAP language and other forms in Tsinghua University. The new form of network performance created a popular mode of science communication with edutainment and theatrical new media formats, which rapidly

\footnotetext{
${ }^{1}$ The CERN video link :

http://v.youku.com/v_show/id_XNDExNDYzNTI=.html
}

promoted the popularity of scientific language style, refreshed the language patterns of internet science communication in the globe.

Nevertheless, we could still clearly point out that the language characteristics of new media also bring negative impacts on science communication. Social media spread scientific information and ideas in fragmentation and personal style, which makes the information-overloaded audience easily get lost. Some science contents in social media draws conclusion with simple description, the lack of empirical analysis, which reduced the depth and effects of science communication to some extent. Besides, the lack of credibility affects people accepting science knowledge from new media in a certain extent. Correct scientific information and science rumors mixed and transmitted together, which makes the audience difficult to identify and accept. Hence, the efficiency of science communication is discounted. Table 
3 summarizes how the language characteristic of new media brings both positive and negative effects on audience and science communication itself.

\section{CONCLUSION AND REMAINING DiSCUSSION}

The revolution of language and the change of thinking in science communication by the use of internet narrative is another enlightenment movement. Behind the value exchange, the basic principles are clearly appeared: problematic - public - standardized (vision). The dismantling of traditional unified language structure may be considered as the third language revolution movement in China. The narrative logic in new media will create patterns of science commination unlike before in the $21^{\text {st }}$ century. Science communication in new media field will trigger a new change of thinking: the entrenched static, linearity and binary thinking will gradually give way to dynamic, mesh and open thinking.

New media liberated scientific thinking and ushered new model of science communication. The language revolution is bound to bring innovation in science popularization products and the consists of scientific community structure. New media further opened doors to the world for Chinese science communication. Along with the advancement of science popularization industry and the further awakening of public's scientific consciousness, new media science popularization products will further segment and expand audiences .China's science popularization products will take on the trend of many categories: international, national and regional, with balance and consideration kept on both inside and outside.

Science communication in the field of new media is facing such a situation with opportunities, risks and challenges occurring together. As professor S. K. Tang argued "We are standing on a periodic historical turning point, how to create new mechanisms and expressions to adapt into new media communication space is an avoidable proposition .Missed this historical node will lead to loss of fresh vitality in the new science communication world." [6] The traditional popular science system led or promoted by the government needs to adapt to the new media characteristics and developing laws. The fast pace modern science communication is bound to require science communicators for better expression and communication skills, qualities and so on. In addition, more issues remaining worthy to be discussed:

1) The problems existing in science communication will inevitably bring more and more public concern and participation. How to make the best use of the circumstances, how to seek and explore communication skills, laws and standards to adapt to the new media context?

2) The new generation and "grassroot" science communication workers have begun to show their dynamism, size and effects. How to cultivate and normalize them in order to achieve the goal of efficient science communication in the new media communication space?

3) The consciousness of science communication from the scientists should be actively guided by policies. How the government performs its roles and being selftransformed in the change of communication process between science popularization subject and public dissemination in the new media context?

4) Scientific communities hold the existing paradigm of scholarly communication, being gradually declined and marginalized by the public's cognitive in the new media. In terms of the future discourse in traditional academic science and technology field, what kind of evolution, competition and risk there will be?

\section{REFERENCES}

[1] X. M. Zhong and Y. P Chen, "Study on science popularization Movements after the foundation of PRC," Journal of Guiyang University, Social Science Edition, vol. 1, pp. 17-22, Jan. 2008.

[2] Z. S. Yang, "Expert review summary," presented at the First National Excellent Science Websites and Columns Selection Activities, Beijing, Sept.17, 2005.

[3] Q. L. Yuan, Introduction to Science for Public Understanding, Beijing, China: Science and Technology Press, 2002, ch. 1, pp. 2-4.

[4] B. N. Liu, "Grass-root popular science in the context of new medium era: An amateur authors' understandings and experience of popular science writing," Journal of Science Popularization Research, vol. 6, pp. 11-15, Dec. 2012.

[5] J. Zhao and L. Wang, "A study on new media and its application in science popularization," Journal of Science Popularization Research, vol. 6, pp. 46-51, Dec. 2012.

[6] S. K. Tang, "Science Communication Strategy Innovation of Basic Science Disciplines in an Era of Web 2.0," Journal of Science Popularization Research, vol. 5, pp.57-58, Oct. 2012.

[7] Z. P. Yin, "The philosophy of science communication studies," Ph.D. dissertation, Dept. Philosophy of Science and Technology, Fudan University, China, 2004.

[8] D. Y. Zhang, S. L. Tao, and Z. Y. Guo, Introduction to Science Popularization, 1st ed, Beijing China: Peking University Press, 1983, ch. 1 , pp. 38 .

[9] Z. L. Peng and H. N. Zheng, "Study on employees participation in enterprise management in new media era," Journal of Science and Technology Management, vol. 6, pp. 214-217, March, 2012.

[10] K. Cao, "Mass media science communication - A case study on southern metropolis daily practice," Journal of Science and Technology Management, vol. 18, pp. 215-240, Sept. 2011.

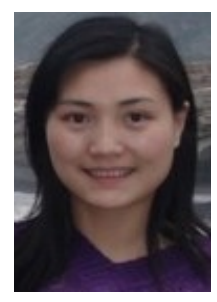

Li Zhao was born on $10^{\text {th }}$ Jan, 1985 in China. Educational background: Sept.2011-now, PhD student majored in Communication Administration, University of Science and Technology of China, Hefei City, China. Oct. 2006 - Nov. 2007, Master of Arts in Online Journalism, Nottingham Trent University, UK .Sept. 2002 - June. 2006, Double Bachelor Degrees in Law \&Journalism, Chongqing Normal University, Chongqing, China.

She works in Southwest University of Science and Technology as a journalism lecturer in Literature and Arts College (LAAC) since 2008.In the past few years; She has published more than 10 academic papers on various sorts of journals in her research field of journalism, science communication, film study and new media. 